\title{
Strengthening Community-based Surveillance Cadre Activeness through Interpersonal Communication and Module Development in Barru District
}

\author{
Andi Zulkifli ${ }^{1 *}$, Andi Indahwaty Sidin $^{2}$, Nasrah Nasrah ${ }^{3}$, Siti Rahmah ${ }^{1}$, A. Ulfiana Fitri ${ }^{4}$ \\ ${ }^{1}$ Department of Epidemiology, Faculty of Public Health, Hasanuddin University, Makassar, Indonesia; ${ }^{2}$ Department of Hospital \\ Management, Faculty of Public Health, Hasanuddin University, Makassar, Indonesia; ${ }^{3}$ Department of Health Promotion, Faculty \\ of Public Health, Hasanuddin University, Makassar, Indonesia; ${ }^{4}$ Department of Health Administration, Faculty of Public Health, \\ Hasanuddin University, Makassar, Indonesia
}

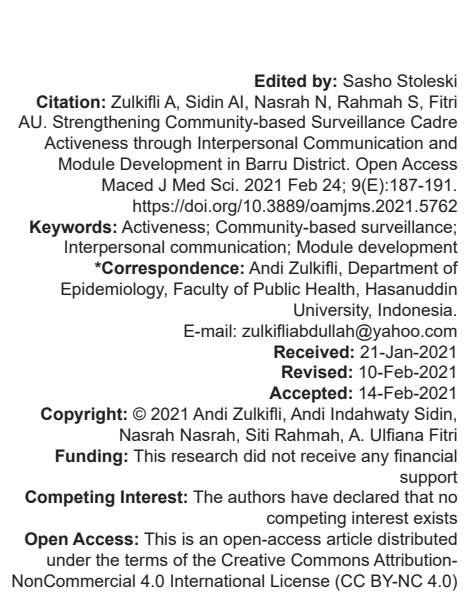

Introduction

Surveillance is the process of collecting, processing and analyzing, and interpreting data systematically and continuously and disseminating information to units that need to take action, both by health workers and by the community [1]. Surveillance is an effort to control infectious diseases [2].

Integrated surveillance implementation in Indonesia is regulated by the Regulation of the Minister of Health of the Republic of Indonesia No. 45 of 2014. It states that surveillance consists of surveillance of infectious diseases, surveillance of non-communicable diseases, environmental health surveillance, health surveillance, and other health surveillance [3]. Integrated surveillance has been developed by the Ministry of Health's innovation program, namely, the community-based surveillance (CBS) program. Community-based integrated surveillance is termed CBS. CBS is the detection and systematic reporting of public health events in a society [4].

\begin{abstract}
(ow activity of community-based surveillance (CBS) cadres reflects the inadequate AIM: This study aimed to increase the activeness of CBS cadres through interpersonal communication and module development.

control group design. This suls including Tanete Riaja subdistrict, Barru subdistrict, Balusu subdistrict, and Mallusetasi subdistrict. The intervention

RESULTS: There are differences in the increase before and after the interpersonal communication intervention

CONCLUSION: There were differences in the increased activity before and after interpersonal communication intervention and module development. There was a higher increase in the interpersonal communication intervention group and module development than only module intervention. It is suggested that the health office provides modules and interpersonal communication training to CBS cadres.
\end{abstract}

CBS is crucial to find symptoms or diseases early as possible to prevent further transmission in the community and identify high-risk populations. It can be used as a priority determination of disease control, can control external outbreaks early as possible, and can be used as material for monitoring and evaluating trends in the development of the community's health situation [5]. The CBS program can be useful if active cadres and community participation support it to collect health information and report it. Efforts that can be made to identify and report health events are by getting active cadres. The presence and activeness of cadres help find symptoms that can be detected early and prevent further transmission in the community and vice versa.

Inactive cadres reduce the success rate of the CBS program in finding symptoms or diseases. Inactive cadres can make changes by providing information related to CBS through the interpersonal communication [6]. Interpersonal communication can influence behavior change due to information giver and recipient facing each other. When interpersonal communication occurs, it supports someone, is honest, 
and sees reactions after communicating. If both parties understand the topic being communicated, the communication can be ensured to be effective. Besides, interpersonal communication will be more effective and easier to understand if accompanied by aids in modules.

The existence of inactive cadres hampered the success of the CBS program. These conditions indicate that the implementation of the CBS program has not been optimal. Therefore, the creativity of CBS cadres needs to be improved by conducting interpersonal communication and developing modules. This research is needed to increase the cadres' performance in finding immunization prevented disease and other health problems. Furthermore, Barru Regency can become a role model for other regency/city health offices.

\section{Methods}

\section{Research site and design}

This research was conducted in Barru Regency, South Sulawesi. This study was a quasi-experimental study with the non-randomized pretest-posttest control group design.

\section{Population and sample}

This study's population was all 48 cadres of CBS. They were not active in several subdistricts of the Barru Regency, including Tanete Riaja subdistrict, Barru, Balusu subdistrict, and Mallusetasi subdistrict. The intervention sample was 20 people in the Tanete Riaja subdistrict. The control sample was 20 people scattered in the subdistricts of Barru, Balusu, and Mallusetasi.

\section{Method of collecting data}

This study used primary and secondary data. Primary data were obtained from CBS cadres who were selected as samples using a questionnaire. Secondary data were obtained from the Barru Regency Health Office in the form of static CBS cadre data.

\section{Data analysis}

The statistical test used was the Chi-square test to see the differences between the intervention group (interpersonal communication and module development) and the control group (CBS module provision) on the respondent's activeness.

\section{Results}

About 14 respondents (70\%) aged 26-45 years old were involved in intervention groups, while 16 respondents $(80 \%)$ were $26-45$ years old and involved in the control group. The respondents' education in the intervention group was mostly junior high school education level of 7 respondents (35\%). They differed in the control group, which mostly had high school education backgrounds of 10 respondents (50\%). About $75 \%$ (15 respondents) of the intervention group were unemployed, and $85 \%$ (17 respondents) were not working in the control group. The respondents' working period in the intervention group was dominated by a $5-6$ years working period of 8 respondents (40\%). It was different from the control group, with a dominated working period of 1-2 years which was 12 respondents $(60 \%)$. The intervention group received more training 3-4 times were 13 respondents $(65 \%)$. In contrast to the control group, case receiving more training 1-2 times, 12 respondents $(60 \%)$ (Table 1$)$.

Table 1: Distribution of respondent characteristics in Barru Regency

\begin{tabular}{|c|c|c|c|c|c|c|}
\hline \multirow[t]{2}{*}{ Variable } & \multicolumn{2}{|c|}{ Intervention } & \multicolumn{2}{|c|}{ Control } & \multicolumn{2}{|c|}{ Total } \\
\hline & $\mathrm{n}$ & $\%$ & $\mathrm{n}$ & $\%$ & $\mathrm{n}$ & $\%$ \\
\hline \multicolumn{7}{|l|}{ Age (years) } \\
\hline $26-45$ & 14 & 70 & 16 & 80 & 30 & 75 \\
\hline $46-65$ & 6 & 30 & 4 & 20 & 10 & 25 \\
\hline Total & 20 & 100 & 20 & 100 & 40 & 100 \\
\hline \multicolumn{7}{|l|}{ Education } \\
\hline Elementary school & 3 & 15 & 1 & 5 & 4 & 10 \\
\hline Junior high school & 7 & 35 & 5 & 25 & 12 & 30 \\
\hline Senior high school & 4 & 20 & 10 & 50 & 14 & 35 \\
\hline Diploma 1 & 1 & 5 & 0 & 0 & 1 & 2.5 \\
\hline Bachelor degree & 5 & 25 & 4 & 20 & 9 & 22.5 \\
\hline Total & 20 & 100 & 20 & 100 & 40 & 100 \\
\hline \multicolumn{7}{|l|}{ Occupation } \\
\hline Not working & 15 & 75 & 17 & 85 & 32 & 80 \\
\hline Working & 5 & 25 & 3 & 15 & 8 & 40 \\
\hline Total & 20 & 100 & 20 & 100 & 40 & 100 \\
\hline \multicolumn{7}{|l|}{ Working period (years) } \\
\hline $1-2$ & 7 & 35 & 12 & 60 & 19 & 47.5 \\
\hline $3-4$ & 5 & 25 & 4 & 20 & 9 & 22.5 \\
\hline $5-6$ & 8 & 40 & 4 & 20 & 12 & 30 \\
\hline Total & 20 & 100 & 20 & 100 & 40 & 100 \\
\hline \multicolumn{7}{|l|}{ Training (times) } \\
\hline $1-2$ & 3 & 15 & 12 & 60 & 15 & 37.5 \\
\hline $3-4$ & 13 & 65 & 4 & 20 & 17 & 42.5 \\
\hline $5-6$ & 4 & 20 & 4 & 20 & 8 & 20 \\
\hline Total & 20 & 100 & 20 & 100 & 40 & 100 \\
\hline
\end{tabular}

The relationship between age and activeness of respondents in the intervention group; the value of $p=0.354(p>0.05)$ was obtained. It meant no relationship between age and activeness of CBS cadres. The control group shows that the value obtained was $p=0.032$, indicating a relationship between the CBS cadres' age and activeness. The relationship between education and the respondents' activeness in the intervention group, $p=1.000(p>0.05)$ was obtained. It meant no relationship between education and CBS cadres' activeness. Likewise, the control group obtained $p=1.000(p>0.05)$, meant no relationship between education and CBS cadre activity. The relationship between work and the respondent's activeness obtained statistical test results in the intervention group was $p=0.613(p>0.05)$, which 
meant no job relationship to CBS cadres' creativity. The same was found for the control group, $p=0.539$ ( $p>0.05$ ), which meant no working relationship to CBS cadres' activeness. The relationship between the working period and activeness in the intervention group was found $p=0.735$ ( $p>0.05$ ). It was indicating no relationship between CBS cadres' working period and activeness. Unlike the control group's case, $p=0.047$ $(p<0.05)$ was obtained, showed a relationship between the working period and CBS cadre activeness. The relationship between training and activeness obtained by statistical test results in the intervention group was $p=0.640(p>0.05)$. Hence, there was no relationship between training on CBS cadres' activeness. In contrast to the control group, $p=0.017(p<0.05)$ was obtained, which meant that there was a relationship between training and activeness of CBS cadres (Table 2).

Table 2: The relationship between characteristics and activeness of cadres in Barru Regency

\begin{tabular}{|c|c|c|c|c|c|}
\hline \multirow[t]{3}{*}{ Variable } & \multicolumn{4}{|c|}{ Activeness } & \multirow[t]{3}{*}{$p$-value } \\
\hline & \multicolumn{2}{|c|}{ Intervention } & \multicolumn{2}{|l|}{ Control } & \\
\hline & Active & Not active & Active & Not active & \\
\hline \multicolumn{6}{|l|}{ Age (years) } \\
\hline $26-45$ & 57.1 & 42.9 & 12.5 & 87.5 & $\mathrm{I}=0.354$ \\
\hline $46-65$ & 83.3 & 16.7 & 75 & 25 & $\mathrm{~K}=0.032$ \\
\hline \multicolumn{6}{|l|}{ Education } \\
\hline High & 60 & 40 & 28.6 & 71.4 & $\mathrm{I}=1.000$ \\
\hline Low & 70 & 30 & 16.7 & 83.3 & $K=1.000$ \\
\hline \multicolumn{6}{|l|}{ Occupation } \\
\hline Not working & 60 & 40 & 29.4 & 70.6 & $\mathrm{I}=0.613$ \\
\hline Working & 80 & 20 & 0 & 100 & $K=0.539$ \\
\hline \multicolumn{6}{|c|}{ Working period (years) } \\
\hline $5-6$ & 62.5 & 37.5 & 50 & 50 & $\mathrm{I}=0.735$ \\
\hline $3-4$ & 60 & 40 & 50 & 50 & $\mathrm{~K}=0.047$ \\
\hline $1-2$ & 71.4 & 28.6 & 8.3 & 91.7 & \\
\hline \multicolumn{6}{|l|}{ Training (times) } \\
\hline $5-6$ & 75 & 25 & 75 & 25 & $\mathrm{I}=0.640$ \\
\hline $3-4$ & 53.8 & 46.2 & 25 & 75 & $\mathrm{~K}=0.017$ \\
\hline $1-2$ & 100 & 0 & 8.3 & 91.7 & \\
\hline
\end{tabular}

The difference in the increase of the respondents' activeness before and after interpersonal communication and module development intervention could not be identified statistically. It caused that the intervention group's active respondents were only found during the post-test. Although it could not be identified statistically, the intervention group showed a change. This change could be seen in the pre-test intervention group, with $0-65 \%$ of active respondents changing at the post-test. Likewise, the difference in increased activeness of the control group, which was only given module development, could not be identified. The control group's active respondent was only found during the post-test. Although it could not be identified statistically, the control group showed a change. At the pre-test, this change in the control group was $0-25 \%$ of active respondents changing at the post-test. The results showed that both the intervention and control groups had changed, the intervention was $65 \%$, and the control group was $25 \%$. The magnitude of the change in activity regarding CBS before and after interpersonal communication intervention and module development was $40 \%$ (Table 3).

The difference in the intervention group's increased activity compared to the control group at the pre-test time could not be identified since only inactive
Table 3: The difference in the increased activity of respondents before and after the intervention (interpersonal communication and modules) and control (modules) in Barru Regency

\begin{tabular}{|c|c|c|c|c|c|c|}
\hline \multirow[t]{2}{*}{ Activeness } & \multicolumn{2}{|c|}{ Pre-test } & \multicolumn{2}{|c|}{ Post-test } & \multicolumn{2}{|c|}{ Total } \\
\hline & $\mathrm{n}$ & $\%$ & $\mathrm{n}$ & $\%$ & $\mathrm{n}$ & $\%$ \\
\hline \multicolumn{7}{|l|}{ Intervention } \\
\hline Not active & 20 & 100 & 7 & 35 & 27 & 67.5 \\
\hline Active & 0 & 0 & 13 & 65 & 13 & 32.5 \\
\hline Total & 20 & 100 & 20 & 100 & 40 & 100 \\
\hline \multicolumn{7}{|l|}{ Control } \\
\hline Not active & 20 & 100 & 15 & 75 & 35 & 87.5 \\
\hline Active & 0 & 0 & 5 & 25 & 5 & 12.5 \\
\hline Total & 20 & 100 & 20 & 100 & 40 & 100 \\
\hline
\end{tabular}

respondents who meet the research requirements were inactive. Table 4 shows that there is a difference in the activeness of the cadres on the posttest between the intervention group and the control group with a value of $p=0.011(p<0.05)$ where the intervention group has higher activity than the control group. Hence, statistically, there was a significant difference in the average score of respondents' activeness in intervention and control groups. After intervening and giving modules, respondents' activeness during the post-test was more inactive in the control group, 15 respondents $(75 \%)$ compared to the intervention group were 7 respondents $(35 \%)$. More active respondents were found in the intervention group, about 13 respondents (65\%) than in the control group, about 5 respondents (25\%).

Table 4: The difference in the increased activeness of respondents in the intervention group (interpersonal communication and modules) compared to the control group (module development) in Barru Regency

\begin{tabular}{|c|c|c|c|c|c|c|c|}
\hline \multirow[t]{2}{*}{ Activeness } & \multicolumn{2}{|c|}{ Intervention } & \multicolumn{2}{|c|}{ Control } & \multicolumn{2}{|c|}{ Total } & \multirow[t]{2}{*}{$p$-value } \\
\hline & $\mathrm{n}$ & $\%$ & $\mathrm{n}$ & $\%$ & $\mathrm{n}$ & $\%$ & \\
\hline \multicolumn{8}{|l|}{ Pre-test } \\
\hline Not active & 20 & 100 & 20 & 100 & 40 & 100 & \multirow{3}{*}{ - } \\
\hline Active & 0 & 0 & 0 & 0 & 0 & 0 & \\
\hline Total & 20 & 100 & 20 & 100 & 40 & 100 & \\
\hline \multicolumn{8}{|l|}{ Post-test } \\
\hline Not active & 7 & 35 & 15 & 75 & 22 & 55 & \multirow[t]{3}{*}{0.011} \\
\hline Active & 13 & 65 & 5 & 25 & 18 & 45 & \\
\hline Total & 20 & 100 & 20 & 100 & 40 & 100 & \\
\hline
\end{tabular}

\section{Discussion}

This study showed differences in increased activity before and after interpersonal communication interventions and module development. Interpersonal communication that takes place intensively by prioritizing balanced quantity and quality aspects will create a strong interpersonal relationship between communicators and communicants. The openness and trust gained from the communication process can help determine changes in a person's attitude and behavior [7]. In terms of communication psychology, the better the interpersonal relationship, the more open people express themselves. The more meaningful communication takes place so that it is easier for someone to make changes in behavior [8].

Three factors influence behavior: Predisposing factors, enabling factors, and reinforcing factors [9]. 
Predisposing factors include age, education, occupation, years of service, and training. The enabling factors include skills and resources needed to perform health behavior, such as costs, distance, and transportation availability. Reinforcing factors consist of the attitudes and behavior of health workers, community leaders, religious leaders, parents, or other officers who are the reference group for community behavior. Based on this theory, the respondents' activeness in this study was not caused by predisposing factors as evidenced by the data obtained (age [0.354], education [1.000], occupation [0.613], years of service [0.735], and training [0.640]). It showed no relationship between age, education, work, years of service, and training on CBS cadres' activeness. Respondents' activeness was also not caused by enabling factors, as evidenced by the results of observations. The research reported that it did not need any traveling the distance from the house to the health center. However, it only needed to collect reports when conducting local health services (posyandu). It could be concluded that these two factors were not the cause of behavior change but were caused by reinforcing factors, mainly interpersonal communication and module development. In Jamaica, the influence of interpersonal communication is a credible source for educating and influencing people related to HIVIAIDS perceptions and risk-taking behavior [10].

This study also showed that there was increased activeness before and after the control module development. Although it could not be identified statistically, the control group showed that there was a change. These changes can be seen in the pre-test control group, with $0 \%$ of active respondents changing at the post-test time to $25 \%$ of active respondents. It showed that significantly the respondent's behavior at the pre-test and post-test had a difference.

Predisposing factors include age, education, occupation, years of service, and training. Enabling factors include skills and resources needed to carry out health behavior, such as cost, distance, and transportation availability. Reinforcing factors include the attitudes and behavior of health workers, community leaders, religious leaders, parents, or other officers who are the reference group for community behavior. Based on this theory, the respondents' activeness in this study was supported by predisposing factors as evidenced by the data obtained that age (0.032), years of service $(0.047)$, and training (0.017). It indicated a relationship between age, years of service, and training on CBS cadre activity. This research was in line with Jumiyati et al. which stated that there is an effect of the module on cadres' practices in exclusive breastfeeding efforts [11].

In this study, both groups had differences before and after interpersonal communication and module development intervention and control module development intervention. Although the two groups both had differences, the study results indicated the difference in respondents' activeness related to CBS. It showed that the difference was higher in the interpersonal communication and module development intervention group $(65 \%)$ than the control group $(25 \%)$. In contrast to the inactive respondents, it was known that after interpersonal communication intervention and module development, there were still 35\% inactive respondents and $75 \%$ in the control group of module development. It could be due to the respondent's intention not to make changes or make changes inactivity.

This study showed a difference in increasing activity in the intervention group than in the control group. The difference in respondents' activeness in the intervention and control groups was supported by the data obtained. At the time of the post-test, there were more inactive respondents in the control group (15 respondents [75\%]) compared to the intervention group (7 respondents [35\%]). More active respondents were in the intervention group (13 respondents [65\%]) than in the control group (5 respondents [25\%]).

Based on the data obtained, there was a higher increase in activity in the interpersonal communication and module development intervention group than in the control module development. It was because dissemination/provision of information through word of mouth is more effective than merely providing modules. The dissemination of information provided through interpersonal communication will influence a person's behavior [6]. Interpersonal communication begins with the personal self. It means that all forms of the process of interpreting messages and judgments about others depart from oneself. Interpersonal communication concerns aspects of message content and interpersonal relationships [12]. It means that interpersonal communication's effectiveness is determined by the quality of the message and the level of relationship between individuals so that new behavior occurs.

This research is in line with Ahmed et al. (2014) which stated that interpersonal communication is more effective in improving practice than print media [13]. Although interpersonal communication is more effective than modules, modules still increase CBS cadres' activeness. Print media play a small role in increasing understanding of disease [14]. Print and audiovisual media play a small role. However, it is not surprising in the community circle because some people are illiterate. Besides, the content and forms of the printed and audiovisual media are not user-friendly or culturally sensitive. Hence, interpersonal communication is quite useful because spreading through word of mouth is more common [15]. Interpersonal communication is effective at low literacy and health-related awareness [16].

\section{Conclusion}

There were differences in increasing activity before and after interpersonal communication 
intervention and module development in this study. There was a higher increase in inactiveness in the interpersonal communication intervention group and module development than in the control group, which was only given module development. It is suggested that the health office provides modules and provides interpersonal communication training to CBS cadres.

\section{References}

1. Nsubuga P, White ME, Thacker SB, Anderson MA, Blount SB Broome CV, et al. Public health surveillance: $A$ tool for targeting and monitoring interventions. In: Jamison DT, Breman JG, Measham AR, Alleyne G, Claeson M, Evans DB, et al., editors. Disease Control Priorities in Developing Countries. $2^{\text {nd }}$ ed. Washington, DC: World Bank; 2006. https://doi. org/10.1596/978-0-8213-6179-5

2. World Health Organization, Public Health Surveillance; 2014. Available from: https://www.who.int/immunization/monitoring surveillance/burden/vpd/en. [Last accessed on 2021 Jan 21].

3. Menteri Kesehatan Republik Indonesia. PERMENKES RI Nomor 45 Tahun 2014 tentang Penyelenggaraan Surveilans Kesehatan. Indonesia: Menteri Kesehatan Republik Indonesia; 2014. https://doi.org/10.20884/1.jih.2018.4.2.115

4. Technical Contributors To The June Who Meeting. A definition for community-based surveillance and a way forward: Results of the WHO global technical meeting, France, 26 to 28 June 2018. Euro Surveill. 2019;24(2):1800681. https://doi. org/10.2807/1560-7917.es.2019.24.2.1800681 PMid:30646977

5. Zulkifli A. Surveilans Pertumbuhan Anak Melalui Pendekatan Learning Organization. Makassar: Pustaka Timur dan Cepsis; 2012.

6. DugganA. Understanding interpersonal communication processesacross health contexts:Advancesinthelastdecadeand challenges for the next decade. J Health Commun. 2006;11(1):93108. https://doi.org/10.1080/10810730500461125 PMid:16546921

7. Wijaya IS. Communication Climate, Organization Climate and Organizational Communication Climate. J Dakwah Tabligh. 2013;14(1):115-26. https:// doi.org/10.24235/orasi.v10i2.5420
8. Rimal RN, Lapinski MK. Why health communication is important in public health. Bull World Health Organ. 2009;87(4):247-a. https://doi.org/10.2471/blt.08.056713

PMid:19551226

9. Cho $H$, Porras $T$, Baik $D$, Beauchemin $M$, Schnall $R$. Understanding the predisposing, enabling, and reinforcing factors influencing the use of a mobile-based HIV management app: A real-world usability evaluation. Int $\mathrm{J}$ Med Inform. 2018;117:88-95. https://doi.org/10.1016/j.ijmedinf.2018.06.007 PMid:30032969

10. Muturi N. The interpersonal communication approach to HIV/ AIDS prevention strategies and challenges for faith-based organizations. J Creat Commun. 2007;2(3):307-27. https://doi. org/10.1177/097325860700200303

11. Jumiyati FN, Nugrahaeni SA, Margawati A. The Impact of Module Increase Knowledge, Attitude and Practice Among The Health Service Providers To Promote Exclusive Breastfeeding. GIZI Indones. 2014;37(1):1.https://doi.org/10.36457/gizindo. v37i1.147

12. Omarzu J, Harvey JH. Interpersonal perception and communication. In: Ramachandran VS, editor. Encyclopedia of Human Behavior. $2^{\text {nd }}$ ed. San Diego: Academic Press; 2012. p. 465-71. https://doi.org/10.1016/b978-0-12-375000-6.00211-1

13. Ahmed SM, Hossain MS, Kabir M. Conventional or interpersonal communication: Which works best in disseminating malaria information in an endemic rural Bangladeshi community? PLoS One. 2014;9(6):e90711. https://doi.org/10.1371/journal. pone.0090711

PMid:24603849

14. Akintola O, Lavis JN, Hoskins R. Print media coverage of primary healthcare and related research evidence in South Africa. Health Res Policy Syst. 2015;13(1):68. https://doi. org/10.1186/s12961-015-0051-6

PMid:26563337

15. Cropley L. The effect of health education interventions on child malaria treatment-seeking practices among mothers in rural refugee villages in Belize, Central America. Health Promot Int. 2004;19(4):445-52. https://doi.org/10.1093/heapro/dah406 PMid: 15520038

16. Keating J, Hutchinson P, Miller JM, Bennett A, Larsen DA, Hamainza B, et al. A quasi-experimental evaluation of an interpersonal communication intervention to increase insecticide-treated net use among children in Zambia. Malar J. 2012;11(1):313. https://doi.org/10.1186/1475-2875-11-313 PMid:22958441 